\title{
PRINSIP-PRINSIP JURNALISTIK [BERCIRIKAN] ISLAM
}

\author{
Oleh: Mutiawati
}

\begin{abstract}
Absrak
Suka tidak suka bahwa dunia jurnalistik, baik media cetak maupun media elektronik (komunikasi massa) selalu terlibat dan tidak akan bisa lepas dengan gatekeepers, regulator, media dan filters sebelum pesan sampai kepada khalayak banyak. Sadar atau tidak sadar dalam proses tersebut, pesan bisa mengalami reduksi, defiasi maupun manipulasi oleh berbagai pihak dan kepentingan dengan tujuan mendapatkan efek yang diinginkan pada audience/khlayak ramai. Oleh karena itu jurnalistik pada media komunikasi massa memiliki peran yang signifikan dalam penyampaian pesan terhadap khalayak ramai.

Pada prinsipnya komunikasi secara umum dengan komunikasi Islam adalah berbeda, prinsip komunikasi Islam berupa free and Balance flow pf information yang dipandang lebih adil dan manusiawi bila di lihat komunikasi secara umum hanya sebatas free flow of information. Percaya atau tidak sejarah munculnya dunia pers itu sendiri berasal sejarah perjuangan manusia tentang kebebasan berbicara setiap anggota masyarakat. Maka di Amerika Serikat ada pasal 19 mengatakan bahwa setiap orang mempunyai kebebasan untuk mencari, menerima dan menyebarkan informasi atau idea melalui media massa tanpa ada hambatan. Maka di dunia Barat ada istilah news free flow (pengaliran berita-berita bebas). Maka kita dapat menyaksikan penyebaran berita yang tidak seimbang antara di dunia Timur dan dunia Barat. Begitu berat tugas jurnalistik Islam dalam menyeimbangkan kesenjangan informasi yang diterima khalayak. Setuju atau tidak setuju faktor internal, sosok jurnalis merupakan pihak yang paling disorot dalam penyebaran berita,
\end{abstract}


di samping ada faktor yang lainnya. Di samping itu sebagai makhluk sosial, seorang wartawan juga mempunyai sikap, nilai, kepercayaan dan orientasi tertentu dalam politik, agama, ideologi dan aliran dimana semua komponen itu berpengaruh terhadap hasil kerjanya (media content), sehingga kerap kali media tersebut terlibat dalam sebuah hegemoni (politik,agama, budaya atau ideologi).

\section{Kata Kunci: Prinsip-prinsip, Kode Etik dan Jurnalistik Islam}

\section{Pendahuluan}

Sejarah jurnalistik yang diukir oleh Gutenberg, yang kemudian mengubah Eropa pada abad ke-15 serta melahirkan komunikasi massa melalui penyebaran informasi/berita. Segala yang berkaitan dengan berita inilah yang merupakan masalah sentral dalam kehidupan jurnalistik. ${ }^{1}$ Dilihat dari faktanya, penyebaran berita dilakukan oleh media komunikasi massa, pekerjaannya adalah menceritakan peristiwa-peristiwa, maka kesibukan utama media massa adalah mengkonstruksikan berbagai realitas yang akan disiarkan. Media menyusun realitas dari berbagai peristiwa yang terjadi terjadi hingga menjadi cerita atau wacana yang bermakna. Pembuatan berita di media pada dasarnya adalah penyusunan realitas-realitas hingga membentuk sebuah cerita atau wacana yang bermakna. Dengan demikian seluruh isi media tiada lain adalah realitas yang telah dikonstruksikan (constructed reality) dalam bentuk wacana yang bermakna. ${ }^{2}$ Oleh karena itu profesional jurnalisme sangat dibutuhkan dalam suatu negara yang demokratis, walau apapun bentuk perubahan kedepan, apakah perubahan ekonomi, politik, sosial dan perubahan yang lainnya yang lainnya.

Dalam jurnalistik tidak ada istilah yang dinamakan "jurnalistik Islam", yang ada hanyalah jurnalistik yang bercirikan Islam. Fungsi dan kegiatan yang dilakukannya sama saja seperti jurnalistik pada umumnya, akan tetapi

${ }^{1}$ Muhammad Budyatna, Jurnalistik: Teori dan Praktek (Bandung: Rosdakarya, 2006), h. 3.

2Ibnu Hamad, Konstruksi Realitas Politik dalam Media Massa (Jakarta: Granit, 2004), h.11-12. 
yang menjadi beda dari jurnalistik biasa dengan jurnalistik yang bercirikan Islam ialah berita atau informasi yang disampaikannya. Jurnalistik yang bercirikan Islamiyah, lebih menonjolkan informasi tentang larangan dan perintah Allah swt. Jurnalistik ini bertujuan untuk mempengaruhi khalayak untuk berprilaku sesuai ajaran Islam. ${ }^{3}$ Cara penyampaian jurnalistik yang bercirikan Islam ini jelas berbeda dengan jurnalistik pada umumnya. Jurnalistik yang bercirikan Islam selalu menghindari hal-hal yang bertentangan dengan syariat Islam. Jurnalistik Islam adalah jurnalisti dakwah. Seorang wartawan muslim harus menjadikan jurnalistik Islam sebagai "ideology" dalam profesinya. Karena dakwah merupakan kewajiban yang melekat pada setiap muslim.

Dalam persepektif Islam penanggung jawab jurnalistik terhadap hukum masyarakat, dan jurnalistik itu sendiri tidak cukup, yang lebih penting dari itu adalah, semua yang terlibat dalam pers diminta untuk mempertanggung jawabkan perbuatannya kepada Allah swt: dalam Al-Qur'an Surah Al-Ahzab ayat 71 yang intinya "jurnalistik" dalam melaksanakan tugasnya hendaknya dengan penuh kesadaran bahwa profesinya adalah sebagai amanah Allah swt, umat dan perubahan. Karena itu pers selalu siap mempertanggung jawabkan pekerjaannya kepada Allah swt.

\section{Pengertian Jurnalistik}

Istilah jurnalistik, diambil dari sebuah media yang dikeluarkan oleh Kaisar Romawi, yaitu acta diurna. Acta diurna bukanlah sebuah surat kabar, tetapi hanyalah sebuah papan pengumuman yang dipasang di tengah kota Romawi, yang berisi berita-berita resmi ke caesaran dan berita lainnya, yang setiap orang bebas membaca dan mengutipnya. Selain kata diurnal juga dikenal kata diurnarius atau diurnari, yaitu seseorang yang tugasnya mencari berita. Dari kata-kata inilah kata jurnalistik muncul, diurnari yang sangat terkenal saat itu adalah Chrestus dan Caelius Rufus. ${ }^{4}$

Selain itu jurnalistik juga berasal dari bahasa Belanda yaitu journalistiek, seperti halnya dengan istilah bahasa Inggris (journalism), merupakan terjemahan

\section{h. 2 .}

3Syarifudin, Teknologi Informasi Dakwah (Ambon: al-Mulk Publishing, 2012),

${ }^{4}$ Roy Pakpahan, Penuntun Jurnalistik Terpadu bagi Kalangan LSM (Jakarta INPI-Pact-SMPI, 1998), h. 1. 
dari bahsa latin (Diurnal) yang berarti harian atau setiap hari.atau jurnalistik adalah Journal yang berarti pewartaan atau catatan harian. ${ }^{5}$ Jurnalistik juga berasal darai bahasa Perancis Do jouryang berarti hari. Journal berarti catatan harian tentang hal-hal yang dianggap penting yang terjadi pada hari itu. ${ }^{6}$ Oleh karena itu orang yang melakukan pekerjaan Jurnalistik, dalam istilah ilmu publisistik adalah hal-hal yang berkaitan dengan menyiarkan berita atau ulasan berita tentang peristiwa sehari-hari yang umum dan aktual (catatan tentang kejadian sehari-hari atau dapat juga berarti surat kabar). Secara terminologi jurnalistik diartikan sebagai kegiatan untuk menyiapkan, mengedit dan menulis surat kabar, majalah atau berkala lainnya. ${ }^{7}$ MacDougall menyebutkan bahwa journalisme adalah kegiatan menghimpun berita, mencari fakta, dan melaporkan pristiwa. ${ }^{8}$ Kegiatan untuk mengetahui apa yang terjadi merupakan kunci lahirnya jurnalistik.

Secara sederhana jurnalistik dapat didefenisikan sebagai tekhnik mengelola berita mulai dari mendapatkan bahan sampai menyebarluaskan kepada khalayak, apa saja yang terjadi di dunia ini apakah itu fakta peristiwa atau pendapat yang diucapkan seseorang, jika diperkirakan akan menarik perhatian khalayak, akan merupakan bahan dasar bagi jurnalistik dan akan merupakan bahan berita untuk dapat disebarluaskan kepada masyarakat.

Pada mulanya jurnalistik hanya mengelola hal-hal yang sifatnya informasi saja. ini terbukti pada acta diurna sebagi produk jurnalistik pertama pada zaman Romawi kuno ketika Kaisar Julius Caesar berkuasa. Dalam perkembangan masyarakat selanjutnya, surat kabar yang bisa mencapai rakyat secara massal dipergunakan oleh kaum idealis untuk melakukan sosial control, sehingga surat kabar tidak hanya bersifat informatif, tetapi juga persuasif. Bukan saja menyiarkan informasi, tetapi juga membujuk dan mengajak khalayak untuk mengambil sikap tertentu, agar berbuat sesuatu atau tidak

${ }^{5}$ Onong Uchana Efendy, Ilmu Komunikasi Teori dan Praktek (Bandung: Remadja Rosda Karya, 1988), h. 196.

${ }^{6} \mathrm{~J}$. B. Wahyudi, Komunikasi Jurnalistik Pengetahuan Praktis Kewartawanan Surat Klabar, Majalah, Radio dan Televisi (Bandung: Penerbit Alumni, 1991), h. 86. 'Dja'far Husin Assegaff, JurnalistikMasa Kini: Pengantar ke Praktek Kewartawanan (Jakarta: Ghalia Indonesia, 1985), h. 9.

${ }^{8}$ Muhammad Budyatna, Jurnalistik: Teori dan Praktek (Bandung: Rosda Karya, 2006), h. 15. 
melakukan sesuatu. Bentuk jurnalistik yang bersifat persuasif, adalah tajuk rencana (editoral).

Jurnalistik dalam bentuk sederhana mulai dikenal ketika Julius Caesar kenjadi kaisar Romawi. Waktu itu ia mengeluarkan peraturan agar kegiatankegiatan senat setiap hari diumumkan kepada khalayak dengan ditempel pada semacam papan pengumuman yang dinamakan Acta Diurna. Berbeda dengan media berita masa kini yang datang di rumah para pembaca, pada waktu itu orang-orang yang datang pada media berita. Karena itu disamping ada keinginan untuk membaca berita pada Arca Diurna, sekelompok khalayak merasa segan untuk meninggalkan rumah untuk datang di papan berita itu. ${ }^{9}$

Batasan jurnalistik menurut Adinegoro adalah, keahlian dan keterampilan seseorang dalam mencari, mengumpulkan, mengolah dan menyebar luaskan berita/karangan, artikel kepada khalayak seluas-luasnya dan secepatcepatnya. ${ }^{10}$ Oleh karena itu jurnalistik merupakan ilmu pengetahuan yang mempelajari bagaimana cara atau teknik mencari bahan berita hingga menyusunnya menjadi berita atau laporan yang menarik.

\section{Tugas dan Tanggung Jawab Jurnalistik}

Tugas dan tanggung jawab utama seorang wartawan, bukan tertuju kepada pemilik perusahaan pers, atau kepada redakturnya, bukan pula kepada pemerintahannya atau kepada mereka yang memberikan berita, tugas utamanya adalah untuk khalayak ramai, bukan hanya sebagian/salah satu pihak saja, jikalau seorang wartawan memberikannya kepada salah satu pihak tersebut di atas, ia sebenarnya bukan wartawan yang baik. ${ }^{11}$ Wartawan bebas menginformasikan realitas yang ditemuinya sesuai dengan kaidah dan kode etik jurnalistik yang unversal. Dalam hal menyampaikan realitas berita, seorang wartawan bertanggung jawab terhadap pembacanya.

Jurnalis atau orang yang terlibat dalam komunikasi massa harus

${ }^{9}$ Onong Uchjana Effendy. Ilmu, Teori dan Filsafat Komunikasi (Bandung: Citra Aditiya Bakti, 2003), h. 95-96.

${ }^{10}$ Adinegoro, Publisistik dan Djurnalistik (Jakarta: Gunung Agung, 1961), h. 86. h. 48 .

${ }^{11}$ M. L. Stein, Bagaimana menjadi Wartawan (Jakarta: Bina Aksara, 1988), 
mempunyai tanggung jawab dalam memberitakan sesuatu apa yang diberitakan oleh media massa harus bisa dipertanggungjawabkan. Jadi, jurnalis tidak hanya sekedar menyiarkan informasi tanpa bertanggung jawab akan dampak yang ditimbulkannya. Tanggung jawab ini bisa kepada Tuhan, masyarakat, profesi atau dirinya sendiri.

Tanggung jawab tentunya mempunyai dampak positif. Dampak positif yang terasa adalah media massa akan berhati-hati untuk menyiarkan dan menyebarkan informasi. Media tidak bisa seenaknya memberikan informasi atau mengarang cerita agar mdeianya laris di pasaran. Jurnalis adalah profesi yang dituntutuntuk bertanggungjawab terahadapapa saja yang dikemukakannya. Bahwa tujuan utama dari jurnalis adalah menyediakan informasi yang akurat dan terpercaya kepada warga masyarakat agar dengan informasi tersebut mereka dapat berperan membangun sebuah masyarakat yang bebas.

Mengenai tanggungjawab, LoisW. Hodges dalam Responsible Journalisme menyatakan bahwa ada tiga kategori tanggung jawab yang diterapkan dalam dunia pers, adalah:

1. Tanggung jawab berdasarkan penugasan

2. Tanggung jawab berdasarkan kontrak

3. Tanggung jawab yang timbul dari diri sendiri. ${ }^{12}$

Sebagai sebuah profesi, maka wartawan terikat kepada kode etik dan kriterianya. Kode etik dimaksudkan sebagai norma yang mengikat pekerjaan yang ditekuni, sedangkan kriteria dimaksudkan sebagai alat seleksi karena tidak setiap orang dapat dengan bebas memasuki lingkaran sesuatu profesi. Lakshamana Rao menyebutkan empat kriteria bahwa pekerjaan itu sebagai suatu profesi, adalah:

1. Harus terdapat kebebasan dalam pekerjaan itu

2. Harus ada panggilan dan keterikatan dengan pekerjaan itu

3. Harus ada keahlian

4. Harus ada tanggung jawab yang terikat pada kode etik pekerjaan tadi. ${ }^{13}$

${ }^{12}$ Luwi Ishwara, Catatan-catatan Jurnalisme Dasar (Jakarta: Kompas, 2007), h. $15-16$.

${ }^{13}$ Asep Saeful Muhtadi, Jurnalistik: Pendekatan Teori dan Peraktek (Jakarta: Logos, 1999), h. 35. 
Kebebasan tetaplah penting, hanya dengan kebebasanlah berbagai informasi bisa disampaiakan kepada masyarakat. Media massa yang tidak mempunyai kebebasan dalam menyiarkan beritanya, ibarat sudah kehilangan sifat dasarnya. Bagaimana mungkin ia akan bisa memberitakan kebobrokan dikalangan masyarakat tanpa ada kebebasan yang dimiliki pers untuk mengungkap dan menyiarkan. Selain itu riset Bill Kovach dan Tom Rosenstiel dan daripara ahli media yang tergabung dalam committee joumalistmenyimpulkan bahwa paling tidak ada sembilan inti prinsip jurnalistikyang harus dikembangkan, adalah:

1. Kewajiban pertama jurnalisme adalah pada kebenaran

2. Loyalitas pertama jurnalisme adalah kepada warga masyarakat

3. Inti jurnalisme adalah disiplin untuk melakukan verifikasi

4. Para wartawan harus memiliki kebebasan dari sumber yang mereka liput

5. Wartawan harus mengemban tugas sebagai pemantau yang bebas terhadap kekuasaan.

6. Jurnalisme harus menyediakan forum untuk kritik dan komentar publik

7. Jurnalisme harus berusaha membuat yang penting menjadi menarik dan relevan

8. Wartawan harus menjaga agar berita proporsional dan komprehensif

9. Wartawan itu memiliki kewajiban utama terhadap suara hatinya. ${ }^{14}$

Tanggung jawab tersebut tidak berarti media tidak boleh memiliki kebebasan, tidak berarti pula pengekangan. Kebebasan jurnalistik ini juga mutlak dimilki media massa. Dengan kata lain, kebebasan dan tanggung jawab sama-sama penting. Oleh karena itu kita sering mendengar istilah kebebasan yang bertanggung jawab, semua orang bebas, tetapi bebas disini harus bisa dipertanggung jawabkan dan bukan sebebas-bebasnya. Kebebasan tetaplah penting, hanya dengan kebebasanlah berbagai informasi bisa disampaiakan kepada masyarakat. Media massa yang tidak mempunyai kebebasan dalam menyiarkan beritanya, ibarat sudah kehilangan sifat dasarnya. Bagaimana mungkin ia akan bisa memberitakan kebobrokan dikalangan masyarakat tanpa ada kebebasan yang dimiliki jurnalistik untuk mengungkap dan menyiarkan.

${ }^{14}$ Ishwara, Catatan..., h. 7-13. 
Kewajiban yang diemban wartawan melahirkan tanggung jawab yang harus mereka pikul. Akar dari tanggung jawab ini terutama berasal dari kenyataan bahwa kita ini selain sebagai induvidu juga menjadi anggota masyarakat, dengan keputusan dan tindakan kita, dapat mempengeruhi orang lain. Semakin besar kekuasaan dan kemampuan kita mempengaruhi orang lain, maka semakin besar pula kewajiban moral yang ditanggung.

\section{Kode Etik Jurnalistik}

Kemerdekaan berpendapat, berekspresi, dan pers adalah hak asai manusia yang dilindungi Pancasila, Undang Undang Dasar 1945, dan Deklarasi Hak Asasi Manusia PBB. Kemerdekaan pers adalah sarana masyarakat untuk memperoleh informasi dan berkomunikasi, guna memenuhi kebutuhan hakiki dan meningkatkan kualitas kehidupan manusia. Dalam mewujudkan kemerdekaan pers itu, wartawan Indonesia juga menyadari adanya kepentingan bangsa, tanggung jawab sosial, keberagaman masyarakat, dan norma-norma agama.

Dalam pelaksanaan fungsi, hak, kewajiban dan peranannya, pers menghormati hak asasi setiap orang, karena itu pers dituntut profesional dan terbuka untuk dikontrol oleh masyarakat. Untuk menjamin kemerdekaan pers dan memenuhi hak publik untuk memperoleh informasi yang benar, wartawan Indonesia memerlukan landasan moral dan etika profesi sebagai pedoman operasional dalam menjaga kepercayaan publik dan menegakkan integritas, serta profesionalisme. Atas dasar itu, wartawan Indonesia menetapkan dan menaati kode etik sebagai berikut:

\section{Pasal 1}

Wartawan Indonesia bersikap independen, menghasilkan berita yang akurat, berimbang dan tidak beritikad buruk.

\section{Pasal 2}

Wartawan Indonesia menempuh cara-cara yang profesional dalam melaksanakan jurnalistik.

\section{Pasal 3}

Wartawan Indonesia selalu menguji informasi, memberikan secara berimbang, tidak mencampurkan fakta dengan opini yang menghakimi, serta menetapkan atas praduga tak bersalah. 


\section{Pasal 4}

Wartawan Indonesia tidak membuat berita bohong, fitnah, sadis dan cabul.

\section{Pasal 5}

Wartawan Indonesia tidak menyebutkan dan menyeiarkan identitas korban kejahatan susiala dan tidak menyebutkan identitas anak yang menjadi pelaku kejahatan.

\section{Pasal 6}

Wartawan Indonesia tidak menyalah gunakan profesi dan tidak menerima suap.

\section{Pasal 7}

Wartawan Indonesia memiliki hak tolak untuk melindungi narasumber yang tidak bersedia diketahui identitasnya maupun keberadaannya, menghargai ketentuan embargo, informasi latar belakang, dan "of the record" sesuai dengan kesepakatan.

\section{Pasal 8}

Wartawan Indonesia tidak menulis atau menyiarkan berita berdasarkan prasangka atau diskriminasi terhadap seseorang atas dasar perbedaan suku, ras, warna kulit, agama, jenis kelamin, dan bahasa serta tidak merendahkan martabat orang lemah, miskin, sakit, cacat jiwa atau cacat jasmani.

\section{Pasal 9}

Wartawan Indonesia menghormati hak narasumber tentang kehidupan pribadinya, kecuali untuk kepentingan publik.

\section{Pasal 10}

Wartawan Indonesi segera mencabut, meralat dan memperbaiki berita yang keliru dan tidak akurat disertai dengan permintaan maaf kepada pembaca, pendengar dan atau pemirsa.

\section{Pasal 11}

Wartawan Indonesia melayani hak jawab dan hak koreksi secara propesional.

Penilaian akhir atas pelanggaran kode etik jurnalistik dilakukan dewan pers. Sanksi atas pelanggaran kode etik jurnalistik dilakukan oleh organisasi wartawan dan atau perusahaan pers. 


\section{Jurnalistik Islam}

Ada pepatah sederhana mengatakan "membaca adalah kunci ilmu, sedangkan gudangnya ilmu adalah buku " ungkapan itu sepintas terlihat sederhana akan tetapi jika di simak, memilki makna yang dalam. Sejalan dengan firman Allah SWT. Q.S. al-Alaq ayat pertama "iqra" mengandung makna baca tulis, dari wahyu yang pertama tergambar perintah Allah SWT. Kepada manusia untuk mengggoreskan pena supaya dapat dibaca orang lain. Goresan-goresan pena itu dari dahulu sampai saat ini bahkan sampai akhir zaman nanti dibutuhkan dan dinantikan kebanyakan manusia. Karenanya sejak awal Islam telah mengajak manusia untuk mengenalkan baca tulis, kemudian berkembang di abad moderen ini dikenal dengan media cetak (surat kabar, buku, tabloid, dan lain-lain).

Jurnalistik Islam dapat dimaknai sebagai "suatu proses meliput, mengolah, dan menyebarluaskan berbagai peristiwa dengan muatan-muatan nilai Islam, khususnya yang menyangkut agama dan ummat Islam kepada khalayak, serta berbagai pandangan dengan persepektif ajaran Islam". Dapat juga jurnalistik Islam dimaknai sebagai "proses pemberitaan atau pelaporan tentang berbagai hal yang sarat dengan muatan dan sosialisasi nilai-nilai Islam". Jurnalistik Islam bisa dikatakan sebagai crousade journalism, yaitu jurnalistik yang memperjuangkan nilai-nilai tertentu, yakni nila-nilai Islam. Jurnalistik Islam mengemban misi amar al-ma 'r-f nahi munkar (Q.S. Ali Imran[3]: 104).

Dalam hal ini seorang jurnalis atau wartawan muslim dituntut untuk selalu menjadikan al-Qur'an dan hadis sebagai landasan dalam memberikan informasi kepada khalayak. Hal ini dimaksudkan agar berita yang diperoleh oleh khalayak luas atau masyarakat dapat dipertanggungjawabkan secara langsung oleh sipembuat berita yaitu wartawan itu sendiri. Kelengkapan al-Quran dengan jurnalistik Islam yang membiaskan pengaruh sangat luas, eksis dalam hubungan keduanya yang seakan-akan saudara kembar atau pinang dibelah dua. Bahwa al-Quran kata-kata Tuhan sedangkan jurnalistik adalah "tulisan tangan manusia". ${ }^{15}$

Secara sederhana jurnalis Islam itu dapat difahami seorang dai atau sekelompok umat manusia yang menyampaikan pesan-pesan Islam kepada

${ }^{15}$ Suf Kasman, Jurnalisme Universal: Menelusuri Prinsip-prinsip Dakwah bi al-Qalam dalam al-Quran (Jakarta: Khazanah Pustaka Keilmuan, 2004), h. xi. 
umat manusia. Menyampaikan informasi-informasi/pesan-pesan Islam melalui media semestinya melalui media Islam juga, tapi mampukah media Islam itu benar-benar mewujudkan secara nyata ruh keislaman itu dalam kehidupan media? Dilihat kenyataan sekarang ini begitu dahsyatnya perkembangan media cetak dan media elektronik (komunikasi massa), tapi yang manakah media Islam? berapakah jurnalis Islam yang benar-benar menyampaikan dakwah Islam? Berapa persenkah isi berita tentang dunia Islam? Atau dari sekian banyak media berapa persenkah isi media terhadap pesanpesan / informasi-informasi Islam?

Jurnalistik Islam sangat erat kaitannya dengan komunikasi Islam itu sendiri, komunikasi Islam adalah informasi yanga diterima khalayak pada media informasi. Sedangkan jurnalistik Islam adalah seorang jurnalis/ wartawan atau dapat juga dikatakan da'i yang menyampaikan pesanpesan keislaman kepada khalayak. Komunikasi Islam merupakan bidang kajian baru yang menarik perhatian sebahagian akedemisi di berbagai perguruan tinggi. Seperti pada bulan Januari 1993, jurnal media, culture and society yang terbit di London, memberi liputan kepada komunikasi Islam. Pengakuan satu jurnal komunikasi yang terbit di Barat terhadap komunikasi Islam tersebut dapat dipandang sebagai suatu tantangan bagi kaum intelektual muslim terutama pakar komunikasi untuk mencari identitas sendiri sesuai dengan nilai-nilai agama dan budaya Islam. ${ }^{16}$

Komunikasi Islam yang masih dalam taraf pengembangan, tentu saja masih menggunakan atau meminjam teori-teori komunikasi secara umum, yang kemudian dimodifikasi dengan komunikasi Islam. Melihat kenyataan umur keilmuan komunikasi Islam yang masih tergolong masih muda, maka wajar komunikasi Islam masih menggunakan teori komunikasi secara umum. Melihat latar belakang munculnya komunikasi Islam yang masih baru, tentu memerlukan perjuangan yang masih panjang dan berat bagi jurnalis Islam. Oleh karena itu quo vadis jurnalis Islam? dengan kenyataan bahwa kapitalis lebih dominan di dunia ini, mereka lebih memiliki kekuatan di segala bidang kehidupan. Ditambah lagi dengan keadaan umat Islam itu sendiri terlalu sibuk dengan pemahaman keislaman masing-masing, terlalu sibuk dengan kebenaran partai-partai keislaman masing-masing, sehingga kurang memperhatikan tali persaudaran sesama kaum muslimin.

${ }^{16}$ Syukur Kholil, Komunikasi Islam (Bandung: Citapustaka Media, 2007), h. 6 
Selain itu faktor yang sangat dominan membuat para jurnalistik pada media Islam kurang mampu mengimbangi media Barat tidak lain karena faktor ekonomi dan politik. Para pengamat pengaliran berita Internasional mengatakan bahwa sistem komunikasi massa dikuasai oleh agensi berita internasional dari negara-negara maju, terutama negara-negara Barat. Empat agensi berita berita internasional yang paling besar, yaitu Associated (AP), United Press International (UPI) dari Amerika Serikat, Agence France Presse (AFP) dari Perancis, dan Reuter dari Inggris, tetap merupakan sumber utama berita internasional bagi negara-negara Dunia Ketiga. ${ }^{17}$

Karenanya bagaimana dunia Islam/jurnalistik Islam mampu mengimbangi kekutan media Barat supaya Informasi yang mengalir kepada masyarakat seimbang, maka Galtung mengatakan bahwa pengaliran informasi di dunia cendrung tidak seimang (imbalence). Publik Barat hanya sedikit mengetahui tentang Islam, kemudian informasi yang sedikit cendrung bersifat negatif. Akibatnya publik Barat hanya mengetahui Islam sebagai agama yang menyukai tindakan kekerasan, miskin, bodoh, kelaparan dan terkebelakang. ${ }^{18}$ Dasar apa negara Barat membuat berita yang tidak adil terhadap dunia Islam? Apakah dunia barat tidak memiliki etika jurnalistik? Apakah etika jurnalistik itu hanya berlaku bagi dunia Timur?

Begitulah media Barat, undang-undang negara Barat pasal 19Universal Declaration of Human Righ yang mengatakan bahwa setiap orang mempunyai kebebasan untuk mencari, menerima dan menyebarkan informasi atau idea melalui media massa tanpa ada hambatan. pernyataan ini menjadi dasar bagi Amerika Serikat dan sekutu-sekutunya untuk memperjuangkan news free flow (pengaliran berita-berita bebas). ${ }^{19}$

Soal bicara dan berpendapat memang berkaitan dengan sejarah pertumbuhan pers, pers lahir dari sejarah perjuangan manusia tentang kebebasan berbicara setiap anggota masyarakat. Bahkan pada perjalanan selanjutnya, hingga saat ini, pers tetap dipandang sebagai kekuatan moral yang mampu menggerakkan semangat demokrasi. ${ }^{20}$ Dalam hal ini perlu

${ }^{17}$ Syukur Kholil, Liputan Agensi-agensi Berita Internasional tentang Dunia Islam dalam Surat Kabar Indonesia (Medan: 1999), h.1.

${ }^{18}$ Ibid., h. 88.

${ }^{19}$ Ibid., h. 89.

${ }^{20}$ Muhtadi, Jurnalistik.., h. 14. 
digaris bawahi, itulah perbedaan komunikasi Islam dengan komunikasi secara umum. Prinsip komunikasi Islam berbeda dengan prinsip komunikasi secara umum, prinsip komunikasi Islam berupa free and Balance flow pf informationyang dipandang lebih adil dan manusiawi bila di lihat komunikasi secara umum hanya sebatas free flow of information.

Paling tidak dalam komunikasi Islam ada nilai-nilai etika yang menjadi pegangan jurnalis Islam, adalah sebagai berikut:

\section{Jujur}

Kejujuran dalam berkomunikasi, yakni menyampaikan pesannya secara benar dan berdasarkan fakta dan data tidak memutar balikkannya merupakan hal yang utama untuk diperhatikan bagi seorang muslim. Seorang penyamapai berita yang tidak jujur (bohong) sangat begitu dekat dengan kehidupan kita sehari-hari, bahkan dalam pragmentasi sejarah Rasulullah begitu juga dalam tradisi hadist Rasulullah. Istilah hadis maudu ${ }^{\circ}$ (bohong) dapat membawa kepada kesesatan, kebinasaan dan kecelakaan besar. Beberapa ayat al Qur'an yang menegaskan tentang kejujuran ini dengan sebutan șidiq, amanah. Dengan komitmen kejujuran dalam menyampaikan berita seperti di atas, maka seorang muslim dalam berkomunikasi menurut al-Qur'an tidak boleh berdusta. ${ }^{21}$

\section{Adil}

Adil adalah tidak memihak. Dalam menjelaskan proses berkomunikasi al Qur'an telah membimbing kita agar berkomunikasi secara adil dan tidak memihak. Adil dan tidak memihakyang dimaksud disini adalah tidak mengabaikan status sosial seseorang atau kelompok ketika kita harus menyampaikan seluruh informasi. Bagaimana kita agar berkomunikasi atau menyampaiakan informasi secara seimbang baik terhadap kaum kerabat, pejabat dan dengan fakir miskin sekalipun. Kata adil yang erat kaitannya dengan komunikasi atau penyampaian informasi terdapat pada (Q.S. 6: 152)

Seorang jurnalis yang adil, akan menempatkan dirinya untuk tidak menimbulkan keberpihakan. Karena kata adil juga berarti sama dan seimbang

${ }^{21}$ Q.S. Luqman[31]: 6. 
dalam memberikan balasan, seperti qishas, diat dan berbagai pidana lainnya. Seorang jurnalis yang adil juga menyangkut keberanian untuk mengatakan yang benar dan yang salah terhadap siapapun.

\section{Bertanggung jawab}

Bertanggung jawab. Sikap bertanggung jawab merupakan sikap yang sangat penting untuk dipelihara dalam prilaku seorang muslim dalam segala aktifitasnya. Al-Qur'an sangat banyak mengingatkan kita agar bertanggung jawab terhadap setiap pesan dan janji yang telah kita sampaikan. Rasa tanggung jawab secara tegas telah mengingatkan kepada kita ini bukan hanya dikarenakan pesan yang disampaiakan tersebut menyangkut kepentingan seseorang atau kelompok, melainkan kesadaran yang tinggi terhadap Allah Swt. Seorang jurnalis yang bertanggung jawab akan menganalisa setiap perkataan dengan hati-hati, memperhitungkan setiap akibat yang mungkin dan secara sadar menimbang dengan nilai-nilai Islam.

\section{Benar-benar akurat}

Informasi dan pesan yang akurat. Penyampaian informasi yang tidak jelas sumbernya dan valid datanya adalah sangat potensial untuk menimbulkan fitnah. Maka dengan itu al-Qur'an secara tegas telah mengingatkan kepada kita agar sangat berhati-hati dan tidak terjebak kepada informasi bohong.

\section{Dan lain-lain}

Itulah Islam agama yang indah dan sangat toleran terhadap semua agama dan semua golongan manusia, agama yang rahmatallil'alamin. Tergantung kepada orang Islam sajalah yang harus menyadarkan diri, bagaimana dapat menyeimbangkan jurnalis Islam dengan jurnalis barat sebagai media dakwah Islamiyah. Tidak berlebihan jika kita mengatakan bahwa dakwah adalah bentuk yang teristimewa dari komunikasi, maka media-media komunikasi dapat dipergunakan untuk berdakwah.

Walaupunkomunikasilslamterbilangbaru, danbelum mampumenyeimbangkan informasi dengan dunia Barat, tetapi paling tidak di Indonesia pada era reformasi ini, pers berbasis agama bermunculan. Kebanyakan adalah pers Islam. Beberapa penerbitan Islam yang lahir di masa reformasi antara lain Sabili, Hidayah, Suara Islam, Hidayatullah, dan lain-lainnya yang berbasis 
agama. Itu menunjukkan jurnalis Islam cukup peduli terhadap perkembangan dunia pers saat ini.

Disayangkan, yang terjadi sekarang pada sebuah media adalah, media yang lebih ideologis umumnya muncul dengan konstruksi realitas yang bersifat pembelaan terhadap kelompok yang sealiran, dan penyerangan terhadap kelompokyang berbeda haluan. Oleh karena itu untuk menyeimbangkan jurnalisme Islam dengan jurnalis Barat, tidak berlebihan jika penulis menawarkan konsep yang ada di dalam Q.S. Ali 'Imran[3]: 103, dan berpegang teguhlah kamu semuanya pada tali (agama) Allah, dan janganlah kamu bercerai berai...). Ajaran Islam itu tidak hanya sekedar ditulis di atas kertas, tetapi ajaran Islam itu dapat diaplikasikan ke dalam kehidupan sehari-hari. Apapun profesi kita, prinsip-prinsip ajaran Islam wajib dilaksanakan dengan penuh tanggung jawab. Makanya antara jurnalistik secara umum dengan jurnalistik Islam ada segi perbedaan, tidak hanya sekedar menyampaikan informasi, akan tetapi bagaimana informasi dapat merubah manusia ke arah yang lebih baik, adil dan manusiawi.

\section{Prinsip-prinsip Jurnalistik (bercirikan) Islam}

Catatan sejarah Islam menunjukkan, komunikasi Nabi Muhammad Saw. dalam menyampaikan pesan atau informasi mengenai nilai-nilai, dan ajaran Islam, frekuensinya cukup tinggi dan variatif, guna menata kehidupan manusia yang seimbang. Melalui proses komunikasi, Nabi Muhammad telah mengekspresikan ajaran Islam, memberi pengertian, mempengaruhi interpretasi dan merubah prilaku manusia. Pada proses komunikasi yang membawa efek kebersamaan ternyata dapat menciptakan saling kebergantungan antara satu dengan yang lainnya dengan ukhuwah Islamiyah maupun dalam kerangka jihad.

Fenomena menarik lainnya dari isyarat komunikasi Islam adalah, komunikasi berlangsung sebagai tindakan internasional dalam menjawab berbagai persoalan, memunculkan gagasan atau ide-ide yang dimunculkan dari proses komunikasi itu sendiri. Kajian Komunikasi Islam tidak terlepas dari prinsip-prinsip Fundamental begitu juga halnya dengan jurnalistik Islam, yang menjadi krangka dasar bangunan Islam dalam tatanan kehidupan yang seimbang antara duniawi dan ukhrawi. Bangunan Islam dibentuk 
oleh etika religious Islam. Oleh karena itu jurnalistik Islam harus ditopang oleh pilar bangunan itu dalam bergerak menuju masa depan yang lebih baik.

1. Prinsip Tauhid. Dalam Islam pandangan yang palin utama dan paling mendasar mengenai manusia dan jagat raya adalah tauhid. Dari pilar satu memunculkan tuntunan akan pengabdian manusia kepada Tuhan sang Pencipta. Dengan menggunakan konsep ketuhanan, maka jurnalistik Islam dalam merebut tempat bagi manusia, untuk otoritas dan lembaga harus dalam kerangka pengabdian kepada Allah. Dengan demikian konsep tauhid jika dilaksanakan akan memberikan prinsip dalam menentukan batas legitimasi atau suatu sistem dalam jurnalistik Islam.

2. Prinsip Tanggung Jawab. Dalam persepektif agama, maka Islam dilihat sebagai agama yang bersifat mission, dimana syiar-syiar pesannya harus terus berlangsung dalam kehidupan manusia. Dengan prinsip tanggung jawab, maka jurnalistik Islam mempunyai visi dan misi serta komitmen yang tinggi dalam menyadari jurnalistik Islam adalah amanah Sang Khalik yang akan dimintai pertanggung jawabannya. Oleh karena itu pada koridor ini prinsip jurnalistik Islam adalah dalam doktrin "amar ma'ruf nahi munkar" (QS.Ali 'Imran[3]:10).

3. Prinsip ummah/ habl min al-nās. Jurnalistik Islam tidak terlepas dari misi ajaran agama Islam, dimana misi itupun terdapat dalam al-Qur'an dan hadis. Sedangkan pada proses komunikasinya, kedudukan alQur'an dan hadis adalah sebagai sumber/rujukan dari perilaku komunikasi dan pesan-pesan yang disampaiakan. Dilihat dari persepektif ini maka jurnalistik Islam berada pada siklus al-Qur'an dan hadist yang inipun sekaligus menjadi ciri khasnya. Dalam proses komunikasi antar manusiaal-Qur'an telah memberikan ketentuan-ketentuan yang disimpulkan menjadi enam prinsip yaitu: qaulan sadidan (Q.S. al-Nisā'[4]:9, Q.S. al-Ahzab [33]:70), qaulan balighān (Q.S. al-Nisā' [4]: 63, qaulan mays-ran (Q.S. al-Isra' [17]: 28), qaulan layyinān (QS. Țaha [20]: 44), qaulan kariman (QS. al-Isra' [17]: 23), dan qaulan ma'r-fan (QS. al-Nisā' [4]:5). Keenam prinsip ini merupakan kata kunci yang mengajarkan manusia bagaimana seharusnya ia berkomunikasi pada saat komunikasi itu berlangsung. 


\section{Penutup}

Jurnalistik adalah salah satu gatekeeper yang ikut menentukan hitamputihnya informasi pada media komunikasi massa. Maka sangat dibutuhkan profesionalisme seorang jurnalisme Islam dalam menyampaikan Informasi. Fikih Jurnalistik adalah hal-hal yang harus ditempuh, sesuai dengan hukum Islam, dalam berbagai kegiatan jurnalistik yang meliputi mencarai, memperoleh, memiliki, menyimpan, menolah dan menyampaiakn informasi baik dalam bentuk tulisan, suara, gambar, suara dan gambar serta data dan grafik maupun dalam bentuk lainnya dengan media yang tersedia. Atau kumpulan hukum syari' at yang berhubungan sebagian tahap kerja jurnalistik, hingga sampai pada tujuannya. Sehingga apabila seorang jurnalis menempuh hal-hal yang terdapat dalam fikir jurnalistik tersebut maka penulis menyakini akan terciptanya jurnalistik-jurnalistik yang profesional, berakhlak mulia dan disenangi juga disayangi oleh masyarakat pada umumnya, dan kalau diperhatikan antara UU pers dengan kode etik jurnalistik itu sangat sesuai dengan ajaran atau norma-norma dalam Islam. 


\section{DAFTAR PUSTAKA}

Adinegoro, Publisistik dan Djurnalistik (Jakarta: Gunung Agung, 1961). Assegaff, Dja'far Husin, Jurnalistik Masa Kini: Pengantarke Praktek Kewartawanan (Jakarta: Ghalia Indonesia, 1985).

Budyatna, Muhammad, Jurnalistik: Teoridan Praktek (Bandung: Rosdakarya, 2006).

Budyatna, Muhammad, Jurnalistik: Teori dan Praktek (Bandung: Rosda Karya, 2006).

Efendy, Onong Uchana, Ilmu Komunikasi Teori dan Praktek (Bandung: Remadja Rosda Karya, 1988).

Effendy. Onong Uchjana, Ilmu, Teori dan Filsafat Komunikasi (Bandung: Citra Aditiya Bakti, 2003).

Hamad, Ibnu, Konstruksi Realitas Politik dalam Media Massa (Jakarta: Granit, 2004).

Ishwara, Luwi, Catatan-catatan Jurnalisme Dasar (Jakarta: Kompas, 2007).

Kasman, Suf, Jurnalisme Universal: Menelusuri Prinsip-prinsip Dakwah bi al-Qalam dalam al-Quran (Jakarta: Khazanah Pustaka Keilmuan, 2004).

Kholil, Syukur, Komunikasi Islam (Bandung: Citapustaka Media, 2007).

Liputan Agensi-agensi Berita Internasional tentang Dunia Islam dalam Surat Kabar Indonesia (Medan: 1999).

Muhtadi, Asep Saeful, Jurnalistik: Pendekatan Teori dan Peraktek (Jakarta: Logos, 1999).

Pakpahan, Roy, Penuntun Jurnalistik Terpadu bagi Kalangan LSM (Jakarta INPI-Pact-SMPI, 1998).

Stein, M. L., Bagaimana menjadi Wartawan (Jakarta: Bina Aksara, 1988). Syarifudin, Teknologi Informasi Dakwah (Ambon: al-Mulk Publishing, 2012). Wahyudi, J.B., Komunikasi Jurnalistik Pengetahuan Praktis Kewartawanan Surat Klabar, Majalah, Radio dan Televisi (Bandung: Penerbit Alumni, 1991). 